\title{
The effect of processing on inflammatory markers in induced sputum
}

\author{
R. Louis*, J. Shute*, K. Goldring*, B. Perks ${ }^{+}$, L.C.K. Lau*, M. Radermecker ${ }^{+}$, R. Djukanovic*
}

The effect of processing on inflammatory markers in induced sputum. R. Louis, J. Shute, K. Goldring, B. Perks, L.C.K. Lau, M. Radermecker, R. Djukanovic. (C)ERS Journals Ltd 1999.

ABSTRACT: The effects of the mucolytic agent, dithioerythritol (DTE), and the temperature at which sputum processing is conducted on cellular and biochemical markers in induced sputum was assessed.

Samples from healthy and atopic asthmatic subjects were treated with either DTE or phosphate-buffered saline (PBS) at 22 or $37^{\circ} \mathrm{C}$ and compared for cell counts and concentrations of histamine, tryptase, esinophil cationic protein (ECP), free interleukin (IL)-8, immunoglobulin (Ig)A, IL-8/IgA complexes and secretory component (SC). In addition, the influence of DTE on in vitro mediator release from blood eosinophils, basophils and bronchoalveolar lavage (BAL) mast cells was studied.

Processing with DTE improved cytospin quality and increased the cell yield and measurable ECP, tryptase, IgA and SC, but reduced levels of histamine in PBStreated samples and had no effect on IL-8. Cell counts or mediator levels were similar when sputum was processed at 22 or $37^{\circ} \mathrm{C}$, even though DTE induced blood basophils and BAL mast cells to release histamine at $37^{\circ} \mathrm{C}$. In spiking experiments, recovery of added ECP, tryptase, total IL-8 and histamine from sputum was similar in DTE- and PBS-processed sputum, but reduced for free IL-8 in PBS-treated samples.

In conclusion, dithioerythritol improves cell and mediator recovery without causing cell activation when sputum processing is conducted at room temperature. The extent of recovery depends on the mediator studied.

Eur Respir J 1999; 13: 660-667.
*Dept of Medicine, Southampton University, UK. ${ }^{+}$Service de Pneumologie, University of Liege, Belgium.

Correspondence: R. Djukanovic, University Medicine, Level D, Centre Block, Southampton University General Hospital, Southampton, SO16 6YD, UK. Fax: 441703701771

Keywords: Asthma

mediators

mucolytics

sputum

Received: March 241998

Accepted after revision November 201998

This work was supported by the Medical Research Council (in the UK) and the Fond de Recherche Scientifique Medicale, grant number 3453697 (in Belgium). R. Louis was a recipient of a scholarship from the Foundation Leon Frederic, University of Liege, Belgium, and the UCB Institute of Allergy, Brussels, Belgium.
Several studies have shown that sputum induction is safe and gives reproducible sputum cell counts and concentrations of soluble mediators [1-6]. However, the possibility that induction itself or subsequent sputum processing activates airway inflammatory cells has not been entirely ruled out [7], leaving doubt as to whether the findings in sputum accurately reflect mucosal inflammation in vivo. In particular, it remains unclear whether the use of the reducing mucolytic agents, dithioerythritol (DTE), or its optical isomer dithiothreitol (DTT), to homogenize sputum may affect the detection of mediators/proteins in the sputum fluid phase either by interfering with immunoassays or by exerting a direct effect on inflammatory cells. Furthermore, it is not known whether the temperature at which sputum is processed is important for mediator detection and cell differential counts, with some authors conducting this at room temperature $[8,9]$ and others at $37^{\circ} \mathrm{C}[4,6,10-13]$.

To address the above issues evidence has been sought for any effects of DTE on the detection of several inflammatory markers of relevance to airways inflammation, including differential cell counts, eosinophil cationic protein (ECP), tryptase, histamine, interleukin (IL)-8, immunoglobulin (Ig)A, and secretory component (SC). To that effect sputum samples treated with DTE or phosphate- buffered saline (PBS) were compared and the direct effects of DTE on mediator immunoassays were studied. As a further means of investigating the effect of DTE on inflammatory cells, it was investigated whether DTE might itself induce release of mediators from blood-derived eosinophils and basophils and bronchoalveolar lavage (BAL) mast cells. Finally, in order to clarify whether the temperature at which sputum is processed matters with respect to cell recovery and mediator levels, the cell counts and levels of ECP and histamine in the same samples processed with DTE either at room temperature $\left(22^{\circ} \mathrm{C}\right)$ or at $37^{\circ} \mathrm{C}$ were compared.

\section{Methods}

\section{Subjects}

Twenty-four atopic asthmatics treated with inhaled $\beta_{2}$ agonists as required and inhaled corticosteroids $(n=2)$ and 10 nonatopic healthy control subjects underwent sputum induction to study the effects of processing with DTE and PBS. BAL was performed in six consenting patients undergoing diagnostic bronchoscopy. Peripheral blood basophils and eosinophils were obtained from six and seven atopic subjects, respectively. 
The studies were approved by the Southampton University and Hospitals Ethics Committee and the Ethics Committee of the University of Liege.

\section{Sputum induction}

Sputum was induced as previously reported, with $4.5 \%$ hypertonic saline inhaled during four 5-min periods [9]. Before expectoration, subjects rinsed their mouth with water and dried it with tissue paper to minimize saliva contamination. The collected sputum was pooled and kept on ice until processing.

Measurement of sputum concentrations of sodium, calcium and magnesium and osmolarity

Four sputum specimens were randomly analysed for concentrations of $\mathrm{Ca}^{2+}$ and $\mathrm{Mg}^{2+}$, electrolytes which are important for cell activation, and $\mathrm{Na}^{+}$and $\mathrm{Cl}^{-}$and osmolarity, factors which might influence mediator release [14]. The electrolytes were detected using the Beckman Synchron CX7 Analyzer (Fullerton, CA, USA) according to the manufacturer's instructions. Osmolarity was measured using the Advanced Micro-Osmometer (Advanced Instruments, Needham Heights, MA, USA) which utilizes highprecision electronic thermometers to sense the freezing point.

Comparison of effects of processing with PBS or DTE on cell counts and mediator levels

In 13 asthmatics and 10 healthy subjects, sputum specimens were divided into two approximately equal parts using a cell scraper and scissors to cut through more viscous mucus. An equal weight of either $0.01 \mathrm{M}$ DTE $(0.15 \%)$ (Fluka, Gillingham, UK) solubilized in PBS or PBS alone was added. Samples were then agitated for $10 \mathrm{~s}$, rocked for $30 \mathrm{~min}$ at room temperature, and filtered through a $70-\mathrm{mM}$ strainer (Becton Dickinson, Abingdon, UK). The collected fluid was centrifuged at $400 \times g$ for 10 min at $4{ }^{\circ} \mathrm{C}$ and supernatants removed and stored at $-20^{\circ} \mathrm{C}$. The cell pellets were resuspended in $1 \mathrm{~mL}$ of $\mathrm{Ca}^{2+}$ - and $\mathrm{Mg}^{2+}$-free PBS, and the cells counted in a haemocytometer. Cytospins were stained with May-Grünwald-Giemsa, and 600 nonsquamous cells counted. The cytospins were scored for quality $(1=$ bad, $2=$ acceptable, $3=\operatorname{good}$ and $4=$ excellent) by one blinded observer taking into account cell morphology, clarity of the background and contamination with squamous cells.

\section{Measurement of mediators/proteins}

ECP was detected by fluorometric enzyme immunoassay (Pharmacia, Uppsala, Sweden). Tryptase was detected by radioimmunoassay (Pharmacia). Histamine was measured by radioimmunoassay (Serotec, Oxfordshire, UK) in sputum samples. Automated fluorometry (Technicon auto analyser 2, Basingstoke, UK) was used for histamine measurements in studies of histamine release by blood basophils and lung mast cells according to a previously described protocol [15]. Free IL-8, IgA, complexes of IL-8 and $\operatorname{IgA}$, and $\mathrm{SC}$ in sputum samples were assayed by enzyme-linked immunosorbent assay (ELISA) as previously described [9].

In order to investigate whether DTE has an effect on the mediator assays, concentrations of histamine, ECP, tryptase, IL-8, and IgA normally used to construct standard curves were assayed in the presence and absence of $5 \mathrm{mM}$ DTE. For histamine, ECP and tryptase the same concentrations were used to spike sputum samples processed with PBS and DTE to test mediator recovery in pooled samples. For IL-8 recovery, experiments were performed with three separate sputum samples using one concentration of IL-8 $\left(5 \mathrm{ng} \cdot \mathrm{mL}^{-1}\right)$ for spiking which, based on previous experience [9], would give a total amount of IL-8 that is still within the standard curve of the assay. In these samples, both free and total IL-8 were measured, the latter with a commercially available ELISA (PeliKine, Eurogenetics, Hampton, UK). Spiking experiments could not be performed for complexed IL-8 because of the unavailability of purified complexes.

\section{Effect of temperature during sputum processing on cell counts and mediator levels}

In a separate group of 11 asthmatics, sputum cell counts and levels of ECP and histamine in the sputum fluid phase were compared in samples split and processed with DTE for $30 \mathrm{~min}$ either at room temperature $\left(22^{\circ} \mathrm{C}\right)$ or in a water bath at $37^{\circ} \mathrm{C}$. Mediator analysis was performed as described above.

\section{Effect of DTE on in vitro mediator release}

ECP release by peripheral blood eosinophil. The effect of DTE on eosinophil activation was studied by measuring ECP release by $>99 \%$ pure eosinophils obtained from seven atopic subjects by negative immunomagnetic cell separation [16]. Cells $\left(1 \times 10^{6}\right)$ were incubated for $30 \mathrm{~min}$ at 22 or $37^{\circ} \mathrm{C}$ in either $500 \mu \mathrm{L}$ of $5 \mathrm{mM}$ DTE in Hank's buffered saline solution (HBSS) containing $1.25 \mathrm{mM} \mathrm{Ca}^{2+}$ and $0.5 \mathrm{mM} \mathrm{Mg}^{2+}$ (Gibco, Paisley, UK) or $500 \mu \mathrm{L}$ of HBSS alone as a control. Any reaction was stopped by placing the tubes into ice. The tubes were centrifuged at $800 \times g$ for $10 \mathrm{~min}$ at $4^{\circ} \mathrm{C}$, the supernatant removed and stored at $-20^{\circ} \mathrm{C}$.

Histamine release by peripheral blood basophils. Histamine release by peripheral blood basophils was studied as previously reported [17]. Mononuclear cell preparations containing $5-10 \%$ basophils were obtained from six atopic donors by density centrifugation of $50 \mathrm{~mL}$ of blood anticoagulated with ethylenediaminetetraacetic acid (EDTA; diluted $1: 1.5$ with $0.9 \%$ saline) on Percoll (Pharmacia Biotech Ltd., St Albans, UK) at $175 \times g$ for $15 \mathrm{~min}$ at room temperature. The cells were washed twice in PIPES buffer (Sigma, Poole, UK) containing $0.003 \%(\mathrm{w} / \mathrm{v})$ albumin and $0.1 \%(\mathrm{w} / \mathrm{v})$ glucose (PAG) and resuspended in PAG supplemented with $1 \mathrm{mM}$ $\mathrm{CaCl}_{2}$ and $1 \mathrm{mM} \mathrm{MgCl}$ (PAGCM) at $2 \times 10^{4}$ cells $\cdot \mathrm{mL}^{-1}$ for the histamine release assay. 
The cells were incubated with $5 \mathrm{mM}$ DTE in the presence or absence of $4.5 \%$ saline. Histamine release was allowed to proceed for $45 \mathrm{~min}$ at room temperature or $37^{\circ} \mathrm{C}$. In four experiments increasing concentrations of DTE $(0.05,0.5$ and $5 \mathrm{mM})$ were used. At the end of the experiment, the tubes were centrifuged at $150 \times g$ for $3 \mathrm{~min}$ at room temperature, and aliquots of the cell-free supernatant harvested and kept at $-20^{\circ} \mathrm{C}$ until analysis by automated fluorometry. The results were expressed as a percentage of total histamine release in samples lysed with $5 \%$ trichloroacetic acid.

Histamine release by BAL metachromatic cells. Because of possible differences between blood basophils and histamine-releasing cells in the airways, in six experiments histamine release from metachromatic cells (mast cells and basophils) recovered by BAL was assessed from individuals undergoing diagnostic bronchoscopy using methods previously described [18]. As with blood, experiments were performed at room temperature and $37^{\circ} \mathrm{C}$. BAL cells $\left(1 \times 10^{6}\right)$ were incubated for 30 min in $250 \mu \mathrm{L}$ of either HBSS or $5 \mathrm{mM}$ DTE in HBSS (both containing $\mathrm{Ca}^{2+}$ and $\mathrm{Mg}^{2+}$ ). After stopping any reaction in ice, the tubes were centrifuged at $400 \times g$ at $4^{\circ} \mathrm{C}$, supernatants removed and diluted twice in perchloric acid $(0.8 \mathrm{M})$ and stored at $-20^{\circ} \mathrm{C}$ until assay. Histamine was measured and results expressed as for blood.

\section{Statistical analysis}

The cytology and mediator/protein levels were expressed as median (range) and comparisons between treatments made by the Wilcoxon rank sum test. Results of cytospin quality and mediator release in vitro were expressed as mean \pm SEM and difference between DTE and the buffer assessed by a paired Student's t-test. The intraclass coefficient of correlation provided an estimation of the agreement between treatments. This was calculated by a repeated one way analysis of variance (ANOVA) and represented the following ratio: variance between subjects - residual variance/variance between subjects + residual variance +2 (variance within subjects) [19]. Its value can vary between -1 and +1 and a value $>0.6$ reflects good agreement between two measurements [20]. In addition, differences in mediator levels between sputum processed at 22 or $37^{\circ} \mathrm{C}$ as well as those in the extent of in vitro mediator release between DTE and HBSS were shown graphically by plotting the difference against the mean as recommended by BLAND and ALTMAN [21]. The relationships between sputum ECP and absolute eosinophil numbers in several experimental conditions were assessed by linear regression after log transformation of the data. Slopes and y-intercepts were compared by analysis of covariance.

\section{Results}

\section{Sputum osmolarity and electrolyte concentrations}

In four randomly chosen sputum specimens, the $\mathrm{Na}^{+}$ concentrations were $136,191,36$, and $28 \mathrm{mM}$, the $\mathrm{Cl}^{-}$ concentrations were $132,192,35$, and $27 \mathrm{mM}$, the $\mathrm{Ca}^{2+}$ concentrations were $0.09,0.28,0.24$, and $0.23 \mathrm{nM}$, and the $\mathrm{Mg}^{2+}$ concentrations were $0.05,0.12,0.09$, and $0.05 \mathrm{nM}$, respectively. The osmolarity in the same specimens was 268, 361, 86, and 70 mosmol.

\section{Effect of processing with PBS or DTE on cell counts and mediator levels}

Differences between DTE- and PBS-processed sputum regarding cell counts and mediator levels were seen regardless of whether the samples were from asthmatics or healthy subjects. Processing of sputum with DTE increased total cell recovery by a mean $90 \%$ and the number of nonsquamous cells by a mean $123 \%$ without affecting their viability (table 1). Furthermore, the use of DTE decreased the proportion of squamous cells in the cellular suspension by $46 \%$ without an effect on differential counts of nonsquamous cells. The quality of the cytospins was significantly $(\mathrm{p}<0.01)$ better in DTE-processed samples (mean quality score: $3.3 \pm 0.5$ versus $1.6 \pm 0.4$ in PBStreated sputum).

The levels of ECP, tryptase, IgA and SC were also significantly higher, but the concentrations of histamine significantly lower in DTE-treated samples. There were no differences in the levels of either free IL-8 or IL-8 complexed to IgA (table 2).

When added to assay buffers at a final concentration of 5 $\mathrm{mM}$, DTE had no effect on the immunoassays for histamine, tryptase, IL- 8 and $\operatorname{IgA}$, but reduced the detection of ECP by between 30 and $50 \%$ as judged by the effect of DTE on the standard curve for these mediators (fig. 1). However, the recovery of histamine, ECP and tryptase after spiking the sputum was complete and similar in samples treated with DTE or PBS (fig. 1). Free IL-8 added to

Table 1. - Total and differential cell counts in sputum samples treated with phosphate-buffered saline (PBS) or dithioerythritol (DTE) at room temperature

\begin{tabular}{|c|c|c|c|c|}
\hline & PBS & DTE & p-value & $\mathrm{r}$ \\
\hline Weight of sputum $g$ & $\begin{array}{c}2.24 \\
(0.54-5.03)\end{array}$ & $\begin{array}{c}2.06 \\
(0.34-4.95)\end{array}$ & 0.51 & - \\
\hline $\begin{array}{l}\text { Total cell counts } \\
\times 10^{6} \cdot \mathrm{g}^{-1}\end{array}$ & $\begin{array}{c}0.70 \\
(0.17-2.17)\end{array}$ & $\begin{array}{c}1.33 * \\
(0.54-13)\end{array}$ & 0.001 & 0.00 \\
\hline Squamous \% & $\begin{array}{c}11 \\
(0-45)\end{array}$ & $\begin{array}{c}6^{*} \\
(0-15)\end{array}$ & 0.01 & 0.00 \\
\hline $\begin{array}{l}\text { Total excluding } \\
\text { squamous } \times 10^{6} \cdot \mathrm{g}^{-1}\end{array}$ & $\begin{array}{c}0.56 \\
(0.14-2.13)\end{array}$ & $\begin{array}{c}1.25^{*} \\
(0.53-13)\end{array}$ & 0.002 & 0.00 \\
\hline Viability \% & $\begin{array}{c}63.5 \\
(33-100)\end{array}$ & $\begin{array}{c}69 \\
(28-93)\end{array}$ & 0.42 & 0.39 \\
\hline Macrophages \% & $\begin{array}{c}54.8 \\
(19.7-93.4)\end{array}$ & $\begin{array}{c}62.4 \\
(16.7-89.3)\end{array}$ & 0.51 & 0.41 \\
\hline Lymphocytes \% & $\begin{array}{c}2.5 \\
(0.3-8)\end{array}$ & $\begin{array}{c}2.3 \\
(0.6-6.4)\end{array}$ & 0.96 & 0.46 \\
\hline Neutrophils \% & $\begin{array}{c}27.3 \\
(4.3-46)\end{array}$ & $\begin{array}{c}22.8 \\
(7.3-46)\end{array}$ & 0.82 & 0.21 \\
\hline Eosinophils \% & $\begin{array}{c}2 \\
(0-60.3)\end{array}$ & $\begin{array}{c}2.3 \\
(0-48)\end{array}$ & 0.48 & 0.89 \\
\hline Epithelial cells \% & $\begin{array}{c}2.6 \\
(0-24)\end{array}$ & $\begin{array}{c}2.2 \\
(0.3-7.7)\end{array}$ & 0.13 & -0.01 \\
\hline
\end{tabular}

Results are expressed as median (range). *: indicates a significant difference between the two types of processing. p-values are calculated by Wilcoxon test and indicate the significance of differences between PBS and DTE-processed samples. $r$ indicates the value of the intraclass coefficient of correlation. 
Table 2. - Concentrations of soluble parameters in sputum processed with either phosphate-buffered saline (PBS) or dithioerythritol (DTE) at room temperature

\begin{tabular}{|c|c|c|c|c|}
\hline Mediators/proteins & PBS & DTE & p-value & $\mathrm{r}$ \\
\hline $\mathrm{ECP} n g \cdot \mathrm{mL}^{-1}$ & $\begin{array}{c}3.6 \\
(<2-121)\end{array}$ & $\begin{array}{c}12.8^{*} \\
(4.2-2920)\end{array}$ & $<0.0001$ & 0.00 \\
\hline Tryptase $\mathrm{ng} \cdot \mathrm{mL}^{-1}$ & $\begin{array}{c}3.5 \\
(1.2-10)\end{array}$ & $\begin{array}{c}8.8^{*} \\
(2.1-13.6)\end{array}$ & 0.04 & 0.14 \\
\hline Histamine $\mathrm{ng} \cdot \mathrm{mL}^{-1}$ & $\begin{array}{c}2.47 \\
(0.5-7.1)\end{array}$ & $\begin{array}{c}0.95^{*} \\
(0.1-5.5)\end{array}$ & 0.03 & 0.41 \\
\hline $\operatorname{IgA~} \mathrm{mg} \cdot \mathrm{mL}^{-1}$ & $\begin{array}{c}8.6 \\
(2.7-43)\end{array}$ & $\begin{array}{c}16.3^{*} \\
(3.9-37.2)\end{array}$ & 0.015 & 0.22 \\
\hline $\mathrm{SC} \mathrm{mg} \cdot \mathrm{mL}^{-1}$ & $\begin{array}{c}1.2 \\
(0.4-7.5)\end{array}$ & $\begin{array}{c}3.6^{*} \\
(0.6-7.5)\end{array}$ & 0.008 & 0.16 \\
\hline $\mathrm{IL}-8 \mathrm{pg} \cdot \mathrm{mL}^{-1}$ & $\begin{array}{c}0 \\
(0-394)\end{array}$ & $\begin{array}{c}0 \\
(0-527)\end{array}$ & 0.84 & 0.89 \\
\hline IL8/IgA OD & $\begin{array}{c}0.27 \\
(0.13-1.46)\end{array}$ & $\begin{array}{c}0.45 \\
(0.19-1.28)\end{array}$ & 0.45 & 0.40 \\
\hline
\end{tabular}

Results are expressed as median (range). *: indicates a significant difference between the two types of processing. p-Values are calculated by the Wilcoxon test and indicate the significance of the difference between PBS and DTE-treated samples. $r$ Indicates the value of the intraclass coefficient of correlation. ECP: eosinophil cationic protein; Ig: immunoglobulin; SC: secretory component; IL: interleukin; OD: optical density.

sputum was largely $(95.2 \pm 4.4 \%)$ undetectable when sputum was treated with PBS. Significantly more free IL-8 $(38.3 \pm 12.3 \%)$ was detected on processing with DTE. However, recovery of total IL-8 was complete in both DTE- and PBS-processed sputum.

\section{Effect of temperature during sputum processing}

Processing of sputum with DTE either at 22 or $37^{\circ} \mathrm{C}$ resulted in similar cell counts and cell viability (table 3 ). Similarly, there were no differences in sputum histamine and ECP concentrations when comparing samples processed at room temperature or $37^{\circ} \mathrm{C}$, with intraclass coefficients of correlation being 0.82 and 0.94 , respectively (fig. 2).

\section{Effects of DTE on mast cell, basophil and eosinophil mediator release in vitro}

The results of mediator release in the presence or absence of DTE at 22 and $37^{\circ} \mathrm{C}$ are shown in figure 3 as differences between observed concentrations obtained under the different experimental conditions plotted against the mean according to Bland and Altman [21]. When experiments were conducted at room temperature, $5 \mathrm{mM}$ DTE failed to release ECP from peripheral blood eosinophils and histamine from peripheral blood basophils or BAL metachromatic cells (fig. 3). The combination of 5 mM DTE and hypertonicity $(4.5 \% \mathrm{NaCl})$ similarly failed to stimulate histamine release from basophils $(1.2 \pm 0.7$ net release above spontaneous, $\mathrm{p}>0.05)$. Although DTE was unable to trigger significant ECP release from eosinophils, it caused significant release of histamine from BAL cells $(8 \pm 3 \%$ above spontaneous, $\mathrm{p}<0.05)$ and blood basophils $(40 \pm 10 \%$ above spontaneous, $\mathrm{p}<0.05)$ when experiments were carried out at $37^{\circ} \mathrm{C}$ (fig. 3). Additional experiments using blood basophils showed that DTE
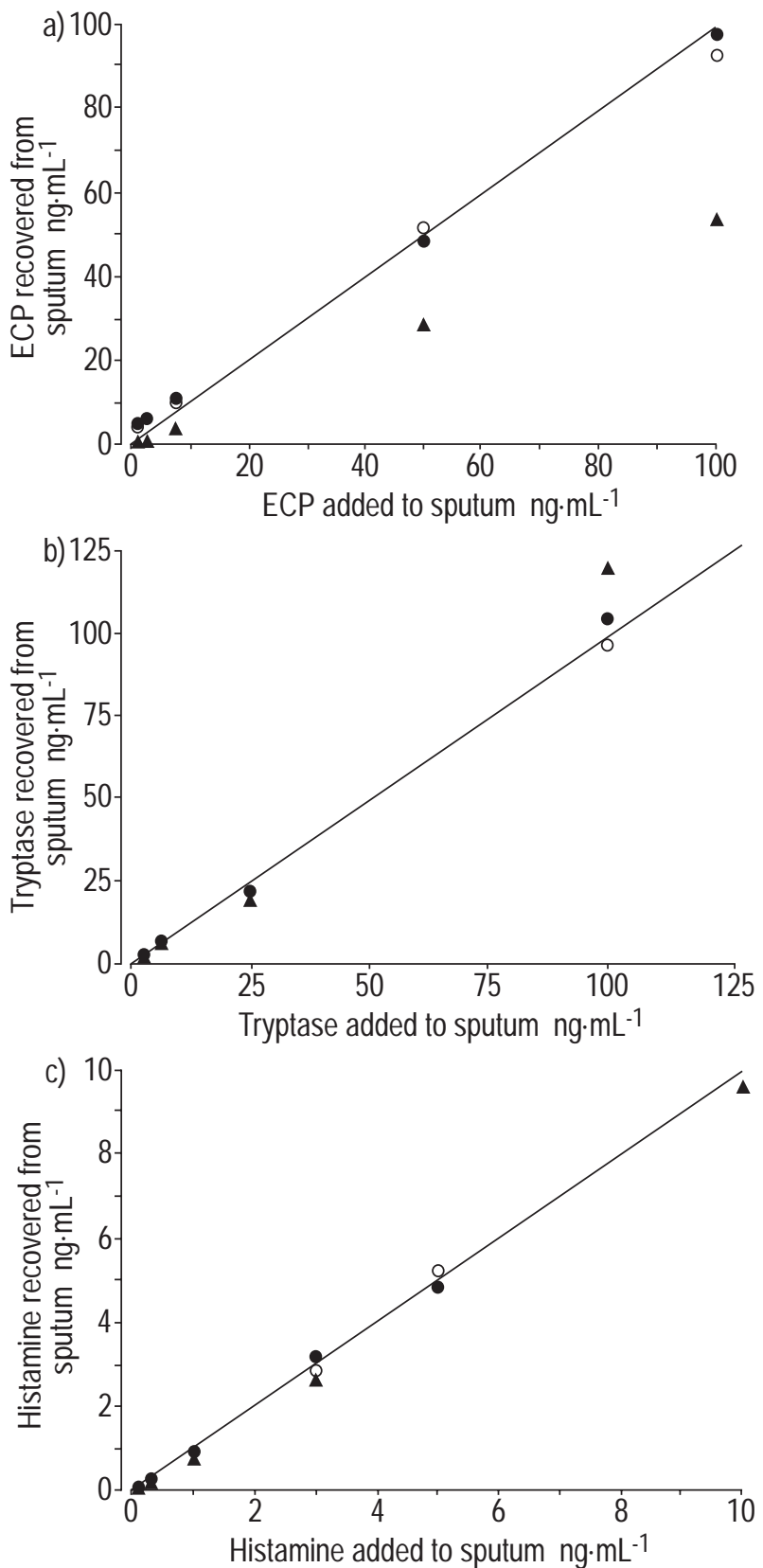

Fig. 1. - Results of spiking experiments to study the recovery of a) eosinophil cationic protein (ECP), b) tryptase, and c) histamine from sputum treated with dithioerythritol (DTE; ๑) or phosphate-buffered saline (PBS; $\bigcirc$ ). In all instances and at all concentrations the recovery was close to $100 \%$. Superimposed on the figures are the effects of DTE on the immunoassays themselves, showing amounts of mediators added to a solution of $5 \mathrm{mM}$ DTE made in buffers (shown on the $\mathrm{x}$-axis) plotted against the amounts detected (y-axis) $(\mathbf{\Delta})$.

induced histamine release in a concentration-dependent manner (net release: $18 \pm 8 \%$ at $0.05 \mathrm{mM}, 32.4 \pm 10 \%$ at 0.5 $\mathrm{mM}$ and $33.8 \pm 8.7 \%$ at $5 \mathrm{mM}$ ) and by a $\mathrm{Ca}^{2+}$-dependent mechanism, since the release of histamine was completely abolished in a milieu without $\mathrm{Ca}^{2+}$ (data not shown). The amount of histamine release induced by $5 \mathrm{mM}$ DTE when $\mathrm{Ca}^{2+}$ concentrations were adjusted to be similar to those measured in sputum $(0.2 \mathrm{mM})$ was $60 \%$ of the release induced by DTE in PAGCM containing $1 \mathrm{mM}$ $\mathrm{Ca}^{2+}$ (data not shown). 
Table 3. - Total and differential cell counts and mediator levels in sputum processed with dithioerythritol (DTE) at either 22 or $37^{\circ} \mathrm{C}$

\begin{tabular}{lcccc}
\hline & $22^{\circ} \mathrm{C}$ & $37^{\circ} \mathrm{C}$ & $\mathrm{p}$-value & $\mathrm{r}$ \\
\hline Weight g & 3.46 & 3.36 & 0.68 & - \\
& $(1.02-4.80)$ & $(0.98-5)$ & & \\
Squamous \% & 10 & 9 & 0.55 & 0.57 \\
& $(3-42)$ & $(3-27)$ & & \\
Total non squa- & 1.28 & 1.11 & 0.27 & 0.59 \\
mous $\times 10^{6} \cdot \mathrm{g}^{-1}$ & $(0.34-3.72)$ & $(0.45-2.73)$ & & \\
Viability \% & 73.5 & 72.5 & 0.73 & 0.62 \\
& $(66-90)$ & $(64-89)$ & & \\
Macrophages \% & 51.5 & 51.5 & 0.84 & 0.96 \\
Lymphocytes \% & $(13-81)$ & $(14-75)$ & & \\
& 1.1 & 1.8 & 0.20 & 0.69 \\
Neutrophils \% & $(0.2-4.8)$ & $(0.2-5.4)$ & & \\
& 24.7 & 33.1 & 0.19 & 0.94 \\
Eosinophils \% & $(4-77.2)$ & $(6.8-75.2)$ & & \\
Epithelial cells \% & 8.8 & 9.8 & 0.74 & 0.96 \\
& $(0.4-34.8)$ & $(0.4-30.4)$ & & \\
ECP ng.mL ${ }^{-1}$ & $(0-31.8)$ & 2 & 0.13 & 0.77 \\
& 206 & 218 & 0.32 & 0.94 \\
Histamine ng.mL & $(14.3-1384)$ & $(10.5-1680)$ & & \\
& 3.07 & 2.86 & 0.28 & 0.82 \\
& $(0.97-2.89)$ & $(1-4.64)$ & & \\
\hline
\end{tabular}

Results are expressed as median (range). ECP: eosinophil cationic protein. p-values are calculated by the Wilcoxon test and indicate the significance of the difference between sputum processed with DTE at 22 or $37^{\circ} \mathrm{C}$. $r$ indicates the value of the intraclass coefficient of correlation.

\section{Relationship between sputum eosinophil numbers and sputum ECP levels}

Irrespective of the method of homogenization (PBS or DTE) and temperature at which this was conducted (22 or $37^{\circ} \mathrm{C}$ ), the concentration of ECP measured in the fluid phase correlated strongly and significantly with the absolute numbers of sputum eosinophils (fig. 4). Similarly, the lines of regression for these two parameters did not differ with respect to their slope or their y-intercept when comparing the different conditions of sputum processing.

\section{Discussion}

This study validates the use of DTE as a mucolytic agent for processing induced sputum. In addition to showing that it improves cytological analysis and detection of mediators, it was shown that DTE does not induce the release of ECP by eosinophils or histamine by basophils and mast cells when the processing of sputum is conducted either at room temperature or $37^{\circ} \mathrm{C}$. The increased quality of cytospins, recovery of cells and detection of ECP, tryptase, IgA and SC in the absence of an effect on differential cell counts or cell viability are likely to be due to improved sputum homogenization and, as a result, release of cells and mediators from mucus clumps. These observations are in keeping with those of EFTHIMIADIS et al. [22] for DTT, the isomer of DTE. They are relevant not only because the cell counts reflect more accurately the degree of cellular infiltration, but also because the use of DTE provides more cells for additional studies such as flow cytometry $[9,23$, 24].
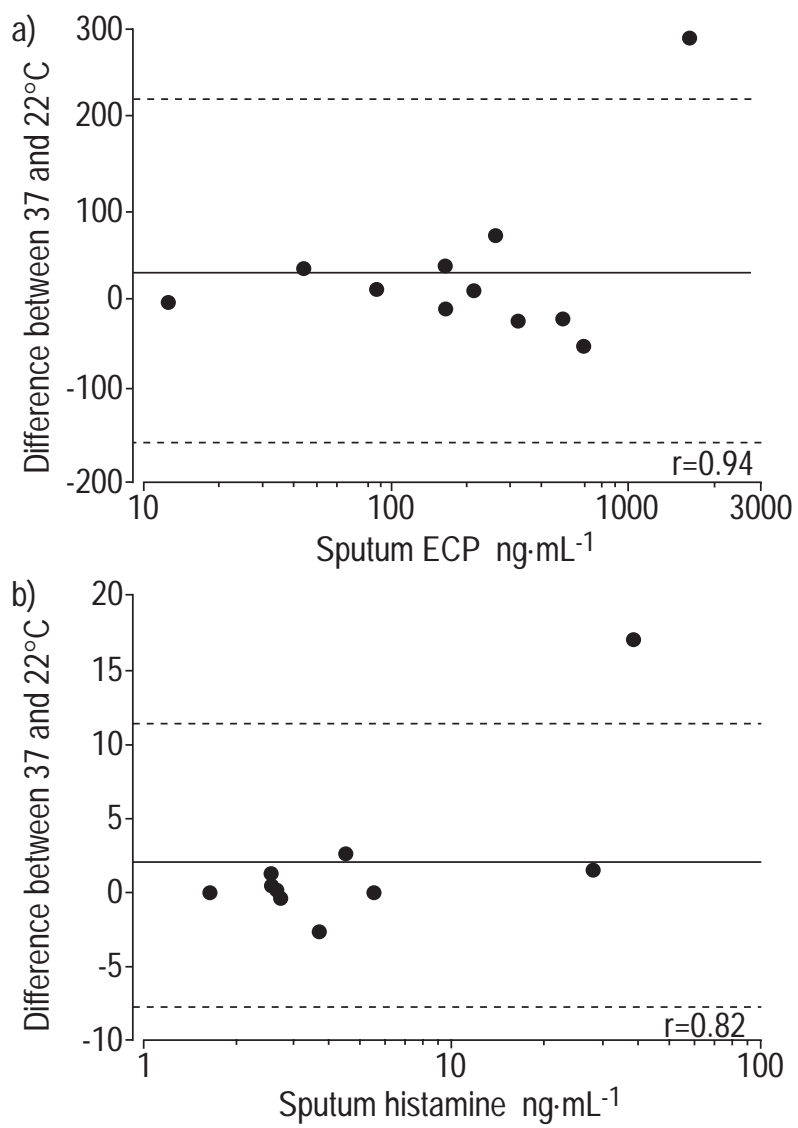

Fig. 2. - Bland and Altman plots for sputum: a) eosinophil cationic protein (ECP); and b) histamine levels when sputum was processed at 37 and $22^{\circ} \mathrm{C}$ in 11 asthmatics. - : mean difference obtained by the following formula, levels at $37^{\circ} \mathrm{C}-$ levels at $22^{\circ} \mathrm{C}$. - - - : \pm 2 sD for the differences between 37 and $22^{\circ} \mathrm{C}$. $r$ indicates the intraclass coefficient of correlation.

One of the aims of this study was to clarify whether DTE and the hypertonicity of saline may have a direct, activating effect on inflammatory cells. Whilst concentrations of salts in sputum were sufficient for cell activation, the osmolarity ( $<360$ mosmol in all samples studied) was below the threshold required to degranulate mast cells and basophils in vitro (400 and 600 mosmol, respectively) [14]. In addition, the combination of hypertonicity of the saline, which probably exceeds that of the final solution in the bronchial lining fluid, and DTE was shown to be unable to induce degranulation of blood basophils in vitro. Thus, it is unlikely that hypertonicity plays any role in a putative $e x$ vivo histamine release during sputum processing.

On its own DTE caused noncytotoxic calcium-dependent degranulation of lung mast cells and blood basophils when experiments were conducted at $37^{\circ} \mathrm{C}$ (not at room temperature), but had no effect on ECP release by blood eosinophils. This raised the possibility that processing at $37^{\circ} \mathrm{C}$ may result in continued histamine release whilst sputum is homogenized. However, no differences were noted in either the levels of histamine or ECP in sputum processed at 22 and $37^{\circ} \mathrm{C}$, with high intraclass coefficients of correlations for the two mediators. This would either suggest minimal contribution of any released histamine to the total amount detected at $37^{\circ} \mathrm{C}$ or the presence of an abundant substrate for DTE in mucus. 

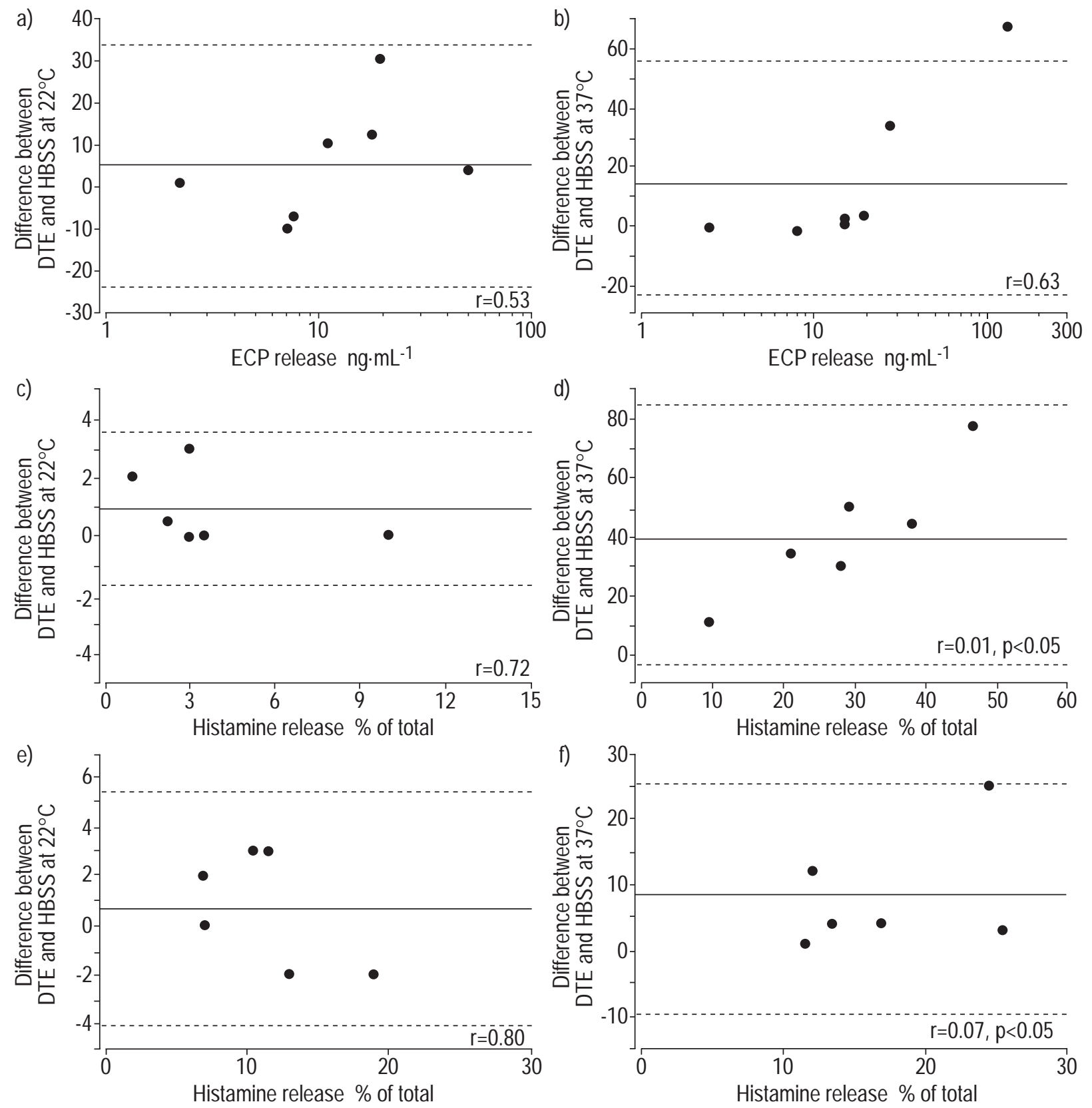

Fig. 3. - Bland and Altman plots for in vitro eosinophil cationic protein (ECP) release by blood eosinophils (a and b), histamine release by blood basophils (c and d) and histamine release by bronchoalveolar lavage (BAL) mast cells (e and f) when experiments were performed at $22^{\circ} \mathrm{C}$ (a, $\mathrm{c}$ and e) or at $37^{\circ} \mathrm{C}$ (b, d and f) with dithioerythritol (DTE; $5 \mathrm{mM}$ ) or Hank's buffered saline solution (HBSS). — : the mean difference obtained by the following formula, mediator release with DTE - mediator release with HBSS. - - - : \pm 2 SD for the difference between DTE and HBSS. r-value indicates the intraclass coefficient of correlation and p-value indicates the significance of the difference calculated by a paired Student's t-test. Significant differences are noted for histamine release from both basophils and BAL mast cells when comparing 22 to $37^{\circ} \mathrm{C}$, with release being higher at $37^{\circ} \mathrm{C}$.

Further evidence that DTE does not cause significant cell activation is the finding of close correlations between eosinophil counts and concentrations of ECP in the sputum fluid phase and the fact that the lines of regression for these two parameters did not differ with respect to slope or yintercept when comparing both samples processed with DTE and PBS and at different temperatures. Nevertheless, based on the experiments with basophils and mast cells in vitro it is probably prudent to conduct sputum processing at room temperature rather than at $37^{\circ} \mathrm{C}$ so as to be absolutely confident about not causing cell activation. The authors are not aware of any specific reasons for processing sputum at $37^{\circ} \mathrm{C}$ other than the recommendation by the manufacturers of these reducing agents, but the present comparison of sputum analyses does not suggest any substantial advantage of processing at $37^{\circ} \mathrm{C}$.

DTE was also found to have no effect on the immunoassays for histamine, tryptase, IgA and IL-8, although it interfered with the fluorometric enzyme immunoassay used to measure ECP. To what extent the latter effect is important is not clear, but the lack of any significant difference in ECP between PBS- and DTE-treated samples suggests that 

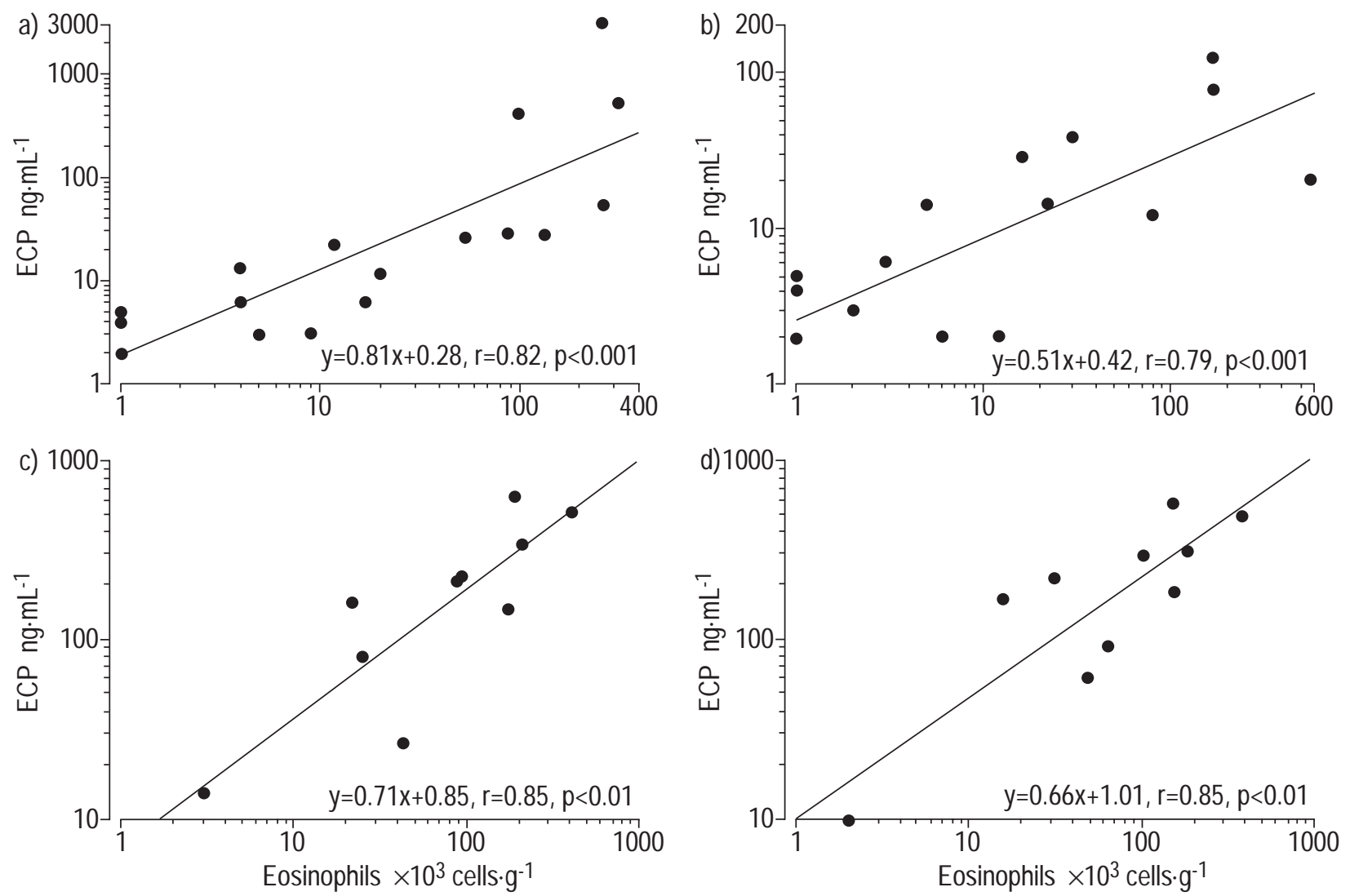

Fig. 4. - Relationship between sputum eosinophil numbers and eosinophil cationic protein (ECP) levels. The relationship in a mixed group including nine healthy subjects and nine asthmatics whose sputum was treated with dithioerythritol (DTE; a) or phosphate-buffered saline (PBS; b) at $22^{\circ} \mathrm{C}$ is shown, along with the relationship in 10 asthmatics whose sputum was treated with DTE at $22^{\circ} \mathrm{C}$ (c) or $37^{\circ} \mathrm{C}(\mathrm{d})$. The linear equation of the regression line is given as well as the Pearson's coefficient of correlation.

the abundant mucus present in sputum may bind sufficient DTE to stop its interference with subsequent assay.

As it was found that DTE failed to induce histamine release from BAL mast cells at room temperature, it is believed that the improved detection of tryptase, a specific marker of mast cell activation, in DTE-treated samples also reflects better mucolysis. Differences in dissociation of mediators from mucus by DTE and PBS are likely to depend on several factors such as size and electrical charge, which determine their ability to form complexes with negatively charged mucus glycoproteins. This is indicated by an inability to detect added IL-8 in its free form unless the samples were treated with DTE, which suggests binding and masking of free IL-8 by macromolecules. Even with DTE, recovery was low when assaying for free IL-8, but was complete when using a kit which detects total IL-8. This highlights the need to consider which epitopes are recognized by the primary antibodies in antibody-dependent assays when analysing sputum. The influence of DTE on protein detection in sputum may be less important for complexes with molecules other than glycoproteins, as suggested by the absence of any difference between DTE- and PBS-treated samples with respect to levels of IL-8/IgA complexes, the predominant form of IL-8 in airways secretions. It has been found that DTE does not release IL-8 from complexes with IgA found in colostrum (unpublished observations), whereas the results shown herein clearly indicate that IL- 8 bound to mucins is released by DTE. Previous studies have shown similar levels of IL-5 and IL-8 in DTE- and PBStreated samples [22], but these results have to be interpreted as measures of total cytokine. The absence of free IL-8 detected in most subjects (median 0 ) is probably a reflection of its binding to $\operatorname{IgA}$, although it is apparent that rare individuals have detectable free IL- 8 which has evaded both binding to IgA and other macromolecules. In stark contrast, the levels of histamine were significantly lower in the DTE-treated samples. This may be related to more rapid degradation by increased activity of histaminases or interference with histamine secretions from an additional source such as bacteria [25]. The fact that DTE had no effect on the immunoassay for histamine rules out any reduction in the ability to detect this mediator.

In conclusion, the use of dithioerythritol facilitates sputum analysis for cell counts and a number of mediators which are now routinely used in research without causing cell activation. It is recommended that processing with dithioerythritol be conducted at room temperature. It remains to be seen whether this reducing agent might have an adverse effect on the ability to detect other potentially important molecules.

\section{References}

1. Pin I, Gibson P, Kolendowicz R, et al. Use of induced sputum cell counts to investigate airway inflammation in asthma. Thorax 1992; 47: 25-29. 
2. Popov T, Gottschalk P, Kolendowicz P, Dolovich J, Powers $\mathrm{P}$, Hargreave FE. The evaluation of a cell dispersion method of sputum examination. Clin Exp Allergy 1994; 24: 778-783.

3. Pizzichini E, Pizzichini M, Efthimiadis A, et al. Indices of airway inflammation in induced sputum: reproducibility and validity of cell and fluid-phase measurements. $A m J$ Respir Crit Care Med 1996; 154: 308-317.

4. In't Veen J, de Gouw R, Smith H, et al. Repeatability of cellular and soluble markers of inflammation in induced sputum from patients with asthma. Eur Respir J 1996; 9: 2441-2447.

5. Gershman N, Wong H, Liu J, Malhmeister M, Fahy J. Comparison of two methods of collecting induced sputum in asthmatic subjects. Eur Respir J 1996; 9: 2448-2453.

6. Spanavello A, Migliori G, Sharara A, et al. Induced sputum to assess airway inflammation: a study of reproducibility. Clin Exp Allergy 1997; 27: 1138-1144.

7. Pavord I. Sputum induction to assess airway inflammation: is it an inflammatory stimulus? Thorax 1998; 53: 79-80.

8. Keatings VM, Collins PD, Scott DM, Barnes PJ. Differences in interleukin-8 and tumor necrosis factor in induced sputum from patients with chronic obstructive pulmonary disease or asthma. Am J Respir Crit Care Med 1996; 153: 530-534.

9. Louis F, Shute J, Biagi S, et al. Cell infiltration, ICAM-1 expression and eosinophil chemotactic activity in asthmatic sputum. Am J Respir Crit Care Med 1997; 155: 466-472.

10. Gibson P, Girgis-Gabardo A, Morris M, et al. Cellular characteristics of sputum from patients with asthma and chronic bronchitis. Thorax 1989; 44: 693-699.

11. Fahy J, Liu J, Wong H, Boushey H. Cellular and biochemmical analysis of induced sputum from asthmatic and healthy subjects. Am Rev Respir Dis 1993; 147: 1126-1131.

12. Maestrelli P, Caleagni P, Saetta M, et al. Sputum eosinophilia after asthmatic responses induced by isocyanates in sensitized subjects. Clin Exp Allergy 1994; 24: 29-34.

13. Bacci E, Cianchetti S, Paggiaro $\mathrm{P}$, et al. Comparison between hypertonic and isotonic saline-induced sputum in the evaluation of airway inflammation in subjects with moderate asthma. Clin Exp Allergy 1996; 26: 1395-1400.
14. Eggleston PA, Kagey-Sobotka A, Schleimer RP, Lichtenstein LM. Interaction between hyperosmolar and IgEmediated histamine release from basophils and mast cells. Am Rev Respir Dis 1984; 130: 86-91.

15. Siraganian RP. An automated continuous-flow system for the extraction and fluorometric analysis of histamine. $\mathrm{An}$ nal Biochem 1974; 57: 383-394.

16. Hansel T, De Vries I, Iff T, et al. An improved immunomagnetic procedure for the isolation of highly purified eosinophils. J Immunol Meth 1992; 145: 105-110.

17. Lavens S, Peachell P, Warner J. Role of tyrosine kinases in IgE-mediated signal transduction in human lung mast cells and basophils. Am J Respir Cell Mol Biol 1992; 1: 637-644.

18. Louis P, Tilkin P, Poncelet M, et al. Regulation of histamine release from human bronchoalveolar lavage mast cells by stem cell factor in several respiratory diseases. Allergy 1995; 50: 340-348.

19. Kramer M, Feinstein A. Clinical biostatistics: LIV. The biostatistic of concordance. Clin Pharmacol Ther 1981; 29: 111-123.

20. Chinn S. Repeatability and method comparison. Thorax 1991; 46: 454-456.

21. Bland J, Altman D. Statistical methods for assessing agreement between two methods of clinical measurements. Lancet 1986; i: 307-310.

22. Efthimiadis A, Pizzichini M, Pizzichini E, Dolovich J, Hargreave F. Induced sputum cell and fluid-phase indices of inflammation: comparison of treatment with dithiotreitol vs phosphate buffered saline. Eur Respir J 1997; 10: 1336-1340.

23. Kidney J, Wong A, Efthimiadis A, et al. Elevated B cells in sputum of asthmatics: close correlation with eosinophils. Am J Respir Crit Care Med 1996; 153: 540544.

24. Pizzichini E, Pizzichini M, Kidney J, et al. Induced sputum, bronchoalveolar lavage and blood from mild asthmatics: inflammatory cells, lymphocyte subsets and soluble markers compared. Eur Respir J 1998; 11: 828834.

25. Sheinman BD, Devalia JL, Davies RJ, Crook SJ, Tabaqchali S. Synthesis of histamine by Haemophilus influenze. BMJ 1986; 292: 857-858. 